\title{
PROTECTION OF RED BLOOD CELLS DURING CARDIOPULMONARY BYPASS
}

\author{
V. I. Cherniy, L. O. Sobanska, N. V. Shestak
}

State Institution of Science «Research and Practical Center of Preventive and Clinical Medicine» State Administrative Department, Kiev

\section{Summary}

Aim. This study was aimed at developing biocompatibility of extracorporeal components due to the use of «adaptation composition» (AdC), reducing the negative impact of perfusion on the state of red blood cell due to the use of fructose-1,6-diphosphate (FDP) to decrease intraoperative hemolysis and tissue hypoxia.

Material and methods. The study included 225 patients undergoing cardiac surgery with cardiopulmonary bypass (CPB). The first group included patients who underwent surgery with the treatment of an extracorporeal circuit by AdC, the second group included patients who were administered the drug with the active substance FDP, the third group was the control group. The oxygenator was treated with $\mathrm{AdC}$ and PDF was administrated according to the protocol. Patient blood was sampling for complete blood cell count $(\mathrm{CBC})$ and blood smears were at 4 stages of surgery: before $\mathrm{CPB}$, at $10 \mathrm{~min}$. CPB-time, at $60 \mathrm{~min}$. CPB-time (rewarming stage) and after separation from $\mathrm{CPB}$. Several parameters were studied: plasma free hemoglobin (plfHb), the erythrocytes osmotic, mechanical resistance of erythrocytes, erythrocyte membrane permeability (EMP), acid hemolysis, the blood smears were stained according to Pappenheim.

Results. The best erythrocyte indices, hemolysis, osmotic, mechanical, acid, urea resistance of erythrocytes were observed in the groups where fructose-1,6-diphosphate and «adaptation composition» were used. At the preoperative stage, hypophosphatemia was detected in $16.8 \%$ out of 225 patients and $26.6 \%$ out of 225 patients have a clear tendency to ones. After CPB, there was no hypophosphatemia in the group where fructose-1,6-diphosphate was administered. The higher peripheralization of reticulocytes, echinocytes, and spherocytes was observed in the control group after perfusion.

Conclusion. The use of $\mathrm{AdC}$ and FDP during $\mathrm{CPB}$ helps to reduce hemolysis and the better state of erythrocytes.

Cardiopulmonary bypass (CPB) can negatively affect the state of red blood cell. The effect of fructose-1,6-diphosphate and «adaptation composition» on the state of erythrocytes during perfusion was studied.

Keywords: cardiopulmonary bypass, fructose-1,6-diphosphate, adaptation composition, erythrocyte, hemolysis, mean cell volume, red cell width distribution, mean cell haemoglobin concentration, hypophosphatemia.

Modern cardiopulmonary bypass (CPB) technologies aim to improve hemocompatibility. Blood contact with the exogenous material and the normal function of blood cells remain the main problems. [1,2] Cell membranes are the first target when are influenced by immune response and hypoxia, their changes can serve as an early signal of the pathological process. A special biological function is performed by the erythrocyte membrane as a universal model that reflects the state of the membranes of the whole organism. Erythrocytes are the most accessible object for research [3]. Contact of blood with the oxygenator surface can cause changes in the membranes of erythrocytes. It can lead to disturbance in the gas transport function, the energy potential and hemolysis of erythrocytes. The state of erythrocytes and their deformability largely depends on the intracellular content of adenosine triphosphate (ATP): decreasing ATP level leads to reduced deformability, and increasing ATP level leads to increased deformability [4]. In conditions of reduced resistance of erythrocytes in hypoxia and as a reaction to blood contact with the oxygenator 
surface, the insufficient energy supply of erythrocytes, erythrocyte membrane destabilization, a change in the shape of the erythrocyte, and hemolysis occur. Changes in the shape of erythrocytes can provide information about the intensity of the pathological process [6]. Hypophosphatemia is one of the disturbance mechanisms of energy supply intracellular homeostasis processes in erythrocytes and it is often found in cardiac surgery patients, patients with intensive care units, especially in patients on mechanical ventilation [7]. There is evidence that insulin resistance and associated hyperglycemia after cardiac surgery results from hypophosphatemia [8]. Increasing the concentration of erythrocyte ATP leads to improved blood rheology and resistance to hemolysis due to better deformability of erythrocytes [9]. The measurement of plasma free hemoglobin (plfHb) is a well-known method but one does not define sublethal trauma of RBC. Induced hemolysis is one of the standard ways to assess the condition of erythrocytes for their resistance to external influences. Acid hemolysis, osmotic and mechanical resistance of erythrocytes are the widely used methods for examining erythrocyte membranes [10]. The complete blood count (CBC) is one of the most common laboratory tests performed in daily practice. Hemoglobin $(\mathrm{Hb})$, hematocrit (Ht), mean corpuscular volume (MCV), Mean corpuscular hemoglobin $(\mathrm{MCH})$, mean corpuscular hemoglobin concentration (MCHC), red cell distribution width (RDW) give us a quick assessment of the state of erythrocytes [11].

\section{THE AIM}

This study was aimed at developing biocompatibility of extracorporeal components due to the use of «adaptation composition» (AdC), reducing the negative impact of perfusion on the morphofunctional state of RBC due to the use of fructose-1,6-diphosphate (FDP) to decrease intraoperative hemolysis and tissue hypoxia. To assess the functional state of erythrocytes as an important marker reflecting the tendency of pathological processes in cells during CPB.

\section{MATERIALS AND METHOD}

The study included 225 patients undergoing cardiac surgery with CPB. They were divided into three groups. The first group ( $\mathrm{Gr} 1, \mathrm{n}=75)$ included patients who underwent surgery with the treatment of an extracorporeal circuit by AdC, the second group ( $\mathrm{Gr} 2, \mathrm{n}=75)$ included patients who were administered the drug with the active substance FDP, the third group ( $\mathrm{Gr} 3, \mathrm{n}=75$ ) was the control group. The distribution of patients into groups is presented in table 1.

The distribution of patients into groups.

Tab. 1

\begin{tabular}{|c|c|c|c|}
\hline & Gr1 (n=75)* & Gr2 (n=75)* & Gr3 (n=75) * \\
\hline Gender: male & $62(82.7 \%)$ & $62(82.7 \%)$ & $61(81.3 \%)$ \\
\hline female & $13(17.3 \%)$ & $13(17.3 \%)$ & $14(18.7 \%)$ \\
\hline Age $(\mathrm{M} \pm \mathrm{m})$, years & $61.92 \pm 8.41$ & $63.39 \pm 9.34$ & $63.05 \pm 8.89$ \\
\hline Weight $(\mathrm{M} \pm \mathrm{m}), \mathrm{kg}$ & $91.36 \pm 15.23$ & $85.7 \pm 11.48$ & $87.67 \pm 16.41$ \\
\hline NYHA** functional class & & & \\
\hline Class II & $6(8.0 \%)$ & $5(6.7 \%)$ & $6(8.0 \%)$ \\
\hline Class III & $55(73.4 \%)$ & $56(74.7 \%)$ & $57(76.0 \%)$ \\
\hline Class IV & $14(18.6 \%)$ & $14(18.6 \%)$ & $12(16.0 \%)$ \\
\hline Surgical operations**: & & & $57(76 \%)$ \\
\hline CABG & $56(74.7 \%)$ & $55(73.3 \%)$ & $4(5.4 \%)$ \\
\hline CABG+LVAR & $3(4 \%)$ & $6(8 \%)$ & $5(6.6 \%)$ \\
\hline AVR & $6(8 \%)$ & $8(10.6 \%)$ & $2(2.7 \%)$ \\
\hline AVR+CABG & $3(4 \%)$ & $2(2.7 \%)$ & $4(5.3 \%)$ \\
\hline MVR & $5(6 / 6 \%)$ & $2(2.7 \%)$ & $3(4 \%)$ \\
\hline MVR+CABG & $2(2.7 \%)$ & $2(2.7 \%)$ & $98.4 \pm 19.8$ \\
\hline CPB-time $(\mathrm{M} \pm m)$, min & $96.27 \pm 18.98$ & $93.85 \pm 19.54$ & \\
\hline
\end{tabular}

*- the difference in parameters in groups by test $\chi 2$ is statistically no significant $(\mathrm{p}>0.05)$

** - NYHA - New York Heart Association Classification

*** CABG - coronary artery bypass grafting, LVAR - left ventricular aneurysm resection, AVR - aortic valve replacement, $\mathrm{MVR}$ - mitral valve replacement.

Management during on-pump CABG surgery includes aortic cross-clamping followed by fibrillation and aortic cross-clamping followed by crystalloid cardioplegia during aortic and mitral valve replacement. In Gr1 The oxygenator was treated with $\mathrm{AdC}$ according to our proposed method [12-14]. In Gr2 PDF was administrated according 
to the protocol [15]. The perfusion system used a membrane oxygenator, roller pump, nonpulsatile flow, and the primed circuit 1.3-1.61 to achieve moderate hemodilution $(\mathrm{Ht}-25 \pm 2$ г/л). Hyperosmolar prime volume with an osmolarity of 510.9 mosmol/1 was used [16]. The mean flow index and mean arterial blood pressure were targeted at $2.5 \mathrm{~L} / \mathrm{min} / \mathrm{m}^{2}$ and $60-80 \mathrm{mmHg}$, correspondingly. CPB was administrated in conditions with moderate systemic hypothermia $\left(32-33^{\circ} \mathrm{C}\right)$. This study complied with the ethics committee approval and written informed consent was obtained from patients. Exclusion criteria included: hereditary fructose intolerance, creatinine clearance below $50 \mathrm{ml} / \mathrm{min}$, hypernatremia, hyperphosphatemia. According to the study protocol, patient blood was sampling for complete blood cell count (CBC) and blood smears were at 4 stages of surgery: before surgery, at $10 \mathrm{~min}$. CPB-time, at $60 \mathrm{~min}$. CPB-time (rewarming stage) and after separation from CPB. Several parameters were studied. Plasma free hemoglobin (plfHb) concentration was measured using the hemoglobin cyanide method [17]. Erythrocytes osmotic resistance was carried out by the method of determining the time up to $50 \%$ hemolysis of a blood sample in a buffer hypotonic glycerol-saline mixture in one tube [18]. The method of Y. V. Ganitkevich, L. I. Chernenko was used for the mechanical resistance of erythrocytes [19]. The result was expressed as\% of hemolyzed cells after mechanical exposure. Erythrocyte membrane permeability (EMP) was determined using the method of urea hemolysis [20]. The concentration of urea in a series of buffered hypotonic solutions was increased and there was studied the degree of hemolysis. Acid hemolysis was determined by I. A. Terskov and I. I. Gitelzon [21]. The blood smears were stained according to Pappenheim.
«MedStart»software program was used for the statistical analyses (licence certificate v. 4. MS 000070-06.07.2009, Y. Y. Liakh, V. G. Gurianov). We checked for the normality of data before further analysis. The ANOVA method was used in the analysis. The $\chi 2$ (Pearson) criterion was used to assess the statistical significance of the differences between two or more relative dates. Group differences were considered statistically significant with a p-value of $<0.05$.

\section{RESULTS AND DISCUSSION}

Before CPB there was no statistically significant difference in all parameters when the three groups were compared.

Before surgery hypophosphatemia was detected in three groups (225 patients): $16.8 \%$ of patients $(n=38)$ have hypophosphatemia and $26.6 \%$ of patients have a clear tendency to ones ( 60 patients have a lower limit of normal phosphorus content in the blood), indicating an initial energy deficiency in this category of patients. There was no statistical difference in the content of phosphorus before CPB in Gr1, Gr2 and Gr 3. In Gr 2 phosphorus levels (1.69 \pm 0.32$)$ were statistically significantly higher after surgery $(\mathrm{p}<0.01)$ and there was no hypophosphatemia. In Gr1 the phosphorus level in the blood $(0.88 \pm 0.25)$ after surgery decreased significantly compared with the baseline ( $\mathrm{p}<0.01$ ). After CPB in Gr1 hypophosphatemia was in $48 \%$ out of 36 patients. In Gr 3 the phosphorus level in the blood $(0.84 \pm 0.29)$ after surgery decreased significantly compared with the baseline ( $\mathrm{p}<0.01$ ). After CPB in Gr 3 hypophosphatemia was in $50,6 \%$ out of 38 patients. Analysis results after $\mathrm{CPB}$ showed a significantly decreased phosphorus level in Gr 2 compared with Gr 1 and Gr3 (p <0.01).

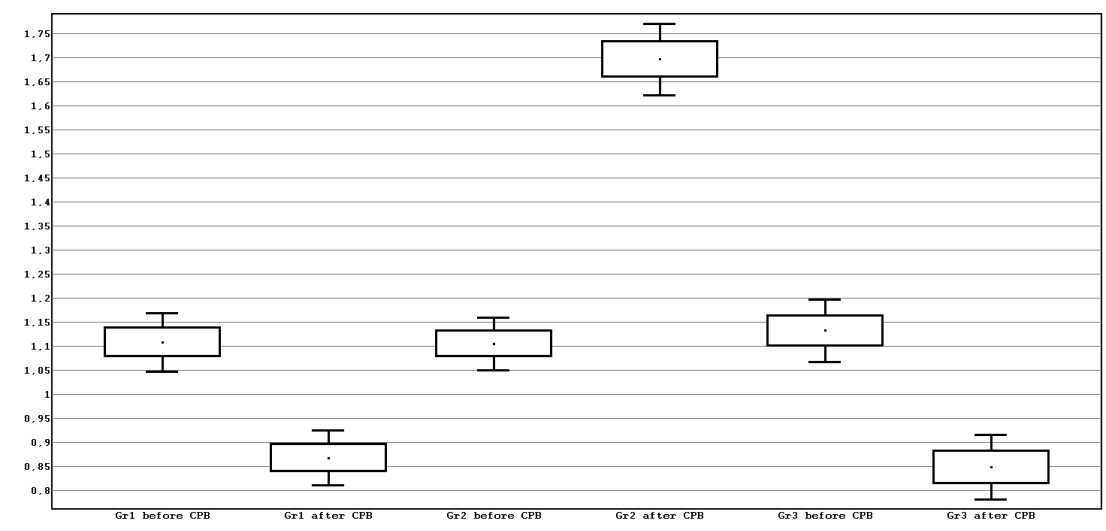

Fig.1 Blood phosphorus level in Gr1, Gr2 and Gr3.

The results of the research showed a significant difference in $\mathrm{HB}$, Ht and $\mathrm{RBC}$ before $\mathrm{CPB}$ and at $10 \mathrm{~min}$. cardiopulmonary bypass time (CPB-time) in Gr 1, Gr 2 and $\operatorname{Gr} 3(\mathrm{p}<0.01)$. There were no significant differences in any parameters at $10 \mathrm{~min}$. CPB-time between Gr1, Gr 2 and $\mathrm{Gr}$ 3. At $10 \mathrm{~min}$. CPB in three groups MCV decreases statistically significantly relative to baseline $(\mathrm{p}<0.01)$ and there is no significant difference in MCV at $10 \mathrm{~min}$. CPBtime between Gr 1, Gr 2 and Gr 3 ( $p=0.504)$. There is no significant difference in MCHC $(p=0.160)$, RDW\% (0.632), RDWa $(\mathrm{p}=0.705)$ at $10 \mathrm{~min}$. CPB-time between Gr 1, Gr 2 and Gr 3. 
At 60 min. CPB-time level of $\mathrm{Ht} 3$ (Gr 3) $28.83 \pm 5.19$ is higher than $\mathrm{Ht} 1(\mathrm{Gr} 1) 25.17 \pm 4.29(\mathrm{p}>0.01)$ and $\mathrm{Ht} 2$ (Gr2) $25.21 \pm 4.17(\mathrm{p}>0.01)$. There is no significant differences in $\mathrm{Ht} 1$ and $\mathrm{Ht} 2(\mathrm{p}=1.0)$. In this period is not a significant difference in $\mathrm{Hb}(\mathrm{p}=0.756)$ and $\mathrm{RBC}$ $(p=0,219)$ between the three groups.

The tendency for a larger increase in MCV is observed in $\mathrm{Gr} 3$ at the warming stage compared to Gr $1(\mathrm{p}>0.01)$ and to Gr 2 (p>0.01). In Gr3 the same tendency is after CPB compared to Gr $1(p>0.01)$ and to $\mathrm{Gr} 2(\mathrm{p}>0.01)$. At 60 min. CPB-time $(p=1.00)$ and after CPB $(p=0.91)$ there is no differences in MCV1 and MCV2. By the end of the operation MCV1 $(p=0.9)$ and MCV2 $(p=1.0)$ reached baseline. After CPB MCV3 is higher than its baseline value $(\mathrm{p}>0.01)$.

Increasing in MCHC $1351.5 \pm 16(\mathrm{p}<0.01)$, MCHC2357.2 $\pm 13.55(\mathrm{p}<0.01)$ and decreasing in MCHC $3(\mathrm{p}<0.001)$ at $60 \mathrm{~min}$. CPB-time compared to before CPB was revealed. There is a significant difference in $\mathrm{MCHC}$ at 60 min. CPB-time between $\mathrm{Gr} 1$ and $\mathrm{Gr} 3(\mathrm{p}<0.01)$ and $\mathrm{Gr} 2$ and $\mathrm{Gr} 3(\mathrm{p}<0.01)$. There is no a significant difference in MCHC at 60 min. CPB-time between Gr 1 and $\mathrm{Gr} 2(\mathrm{p}=0.360)$.

At 60 min. CPB-time RDW\% 3 is decreasing (12.39 \pm 1.33$)$ and RDWa3 (81.94 \pm 12.03$)$ is increasing compared with the baseline parameters in $\mathrm{Gr} 3(\mathrm{p}<0.01)$. Compared with before $\mathrm{CPB}$ and after $\mathrm{CPB}$ in $\mathrm{Gr} 3$ there is a tendency to increased RDWa3 87.22 $\pm 14.29(p<0.01)$ and RDW\%3 $14.75 \pm 1.68(\mathrm{p}<0.01)$. The dynamics of RDW\% 1 and RDWa1 is not statistically significant at all stages of the surgery $(p=0.298)$. The dynamics of RDW\% 1 and RDWa1 is not statistically significant at all stages of the surgery $(p=0.298)$. The dynamics of RDW\% 2 and RDWa2 is not statistically significant at all stages of the surgery $(\mathrm{p}=0.491)$. There is a significant difference in RDW\% and RDWa between Gr 1 and Gr $3(p<0.01)$ and $\mathrm{Gr} 2$ and Gr3 $(p<0.01)$ at $60 \mathrm{~min} . \mathrm{CPB}$-time.

The study of the statistics before $\mathrm{CPB}$ and after $\mathrm{CPB}$ showed that MCHC1 339.9 \pm 13.45 , MCHC2 $341.8 \pm 11.35$ are higher than MCHC3 $323.1 \pm 23.9(\mathrm{p}<0.01)$. The decline of MCHC3 occurs due to an increase in MCV3 $(\mathrm{p}<0.01)$ after CPB.

Parameters of MCV3 and $\mathrm{Ht} 3$ are higher than MCV1 $(p<0.01)$, MCV2 $(p<0.01)$ and Ht1 $(p<0.01)$, $\mathrm{Ht} 2(\mathrm{p}=0.01)$ at stage after separation from CPB. After $\mathrm{CPB}$ there are no statistically significant difference in $\mathrm{Hb}$ $(p=0.188), \operatorname{RBC}(p=0.452)$ in the three groups.

Hemolysis during extracorporeal circulation is the result of the destruction of the $\mathrm{RBC}$ membrane with the breakdown and release of plasma free hemoglobin. There are no significant differences in the level of hemolysis between the before CPB and at $10 \mathrm{~min}$. CPB-time in the three groups $(p=0.062)$, starting from $60 \mathrm{~min}$. CPB-time and after CPB hemolysis was higher in Gr3 $(\mathrm{p}<0.01)$. There is no significant difference in the level of hemolysis between the $\mathrm{Gr} 1$ and $\mathrm{Gr} 2$ at $60 \mathrm{~min}$. CPB-time $(\mathrm{p}=0.604)$ and after CPB $(3=0.570)$.

There were changes in the shape and size of erythrocytes at morphological research after CPB (Fig. 2 $D, F, G)$.

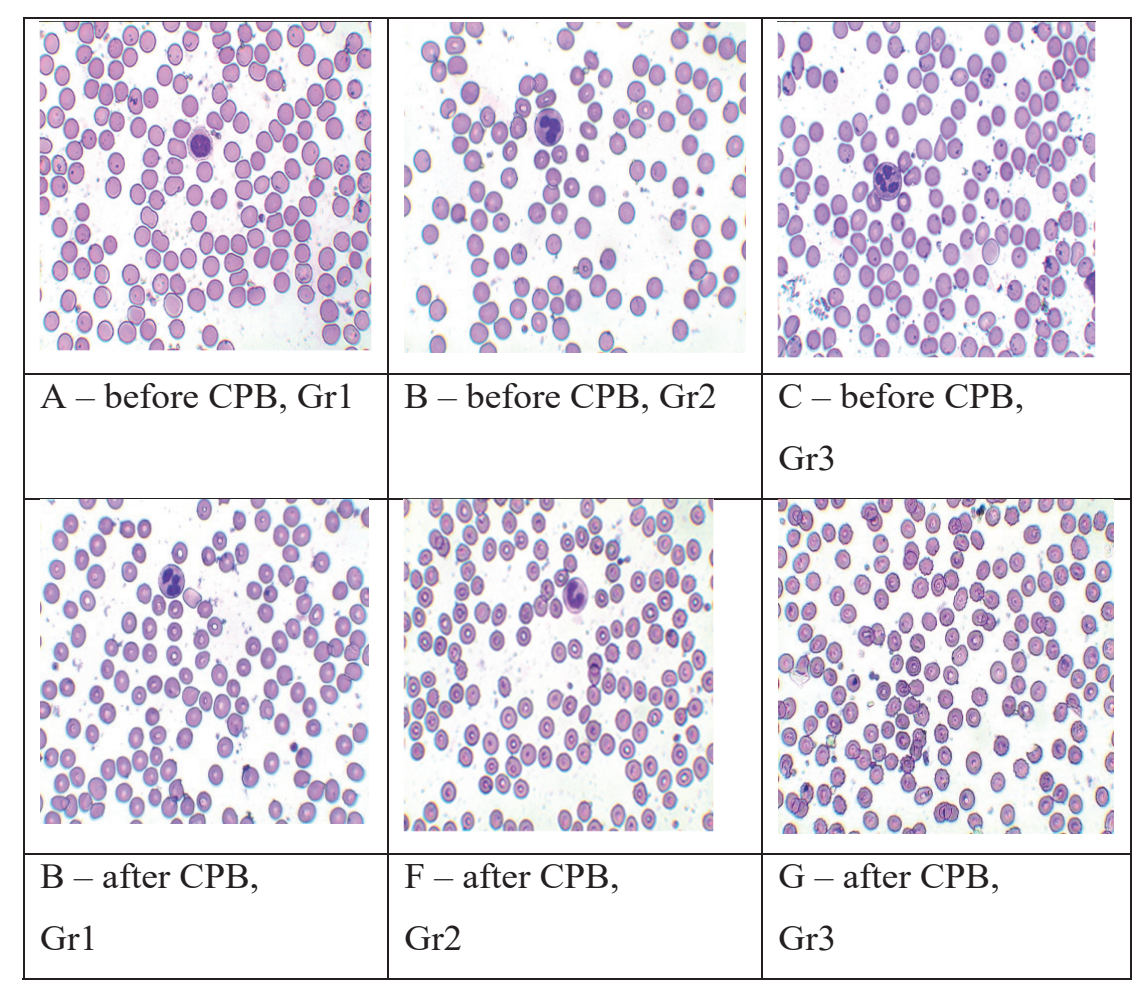

Fig. 2 Distinctive changes in the erythrocyte morphology in Gr1, Gr2 and Gr3. 
After CPB in Gr 3, the microscopy of blood smear detects the presence of a large number of spherocytes and echinocytes (Fig. 2 G).

It was found that before $\mathrm{CPB}$ the baseline\% content of reticulocytes, echinocytes, and spherocytes in the three groups was not statistically significant. After CPB in Gr3 the higher content of reticulocytes $(p<0.01)$, echinocytes $(\mathrm{p}<0.01)$ and spherocytes $(\mathrm{p}=0.02)$ compared with $\mathrm{Gr} 1$ and Gr2 is observed.

In $\mathrm{Gr} 3$ after separation from $\mathrm{CPB}$, there was a decrease in the mechanical resistance of erythrocytes (tab.2) compared with Gr1and Gr2 (p>0.01). There was no difference in the mechanical resistance of erythrocytes between $\mathrm{Cr} 1$ and $\mathrm{Gr} 2(\mathrm{p}=1.00)$.

After CPB results had a tendency to better time of acid hemolysis $50 \%$ of erythrocytes in Gr2 compared with Gr $3(p=0.05)$. At this stage, there was a reduced resistance to acid hemolysis in Gr 3 compared with $\operatorname{Grl}(\mathrm{p}>0.01)$. Comparing Gr 1 with Gr 2, we got better acid resistance in Gr1 ( $p=0.02)($ tab.2).

The study of osmotic resistance of erythrocytes (ORE) showed that after CPB in $\operatorname{Gr} 1(p=0.03)$ and $\operatorname{Gr} 2(p=0.05)$ there was a tendency to more resistant to hypoosmotic factor compared with Gr3 (tab.2).

Parameters of erythrocyte resistance before and after CPB.

\begin{tabular}{|c|c|c|c|c|c|c|c|}
\hline \multirow[b]{2}{*}{ Parameters } & \multicolumn{6}{|c|}{ Mean \pm SD } & \multirow[b]{2}{*}{ p } \\
\hline & Gr1 $(n=75)$ & Gr $2(n=75)$ & $\mathrm{p}^{*}$ & $\begin{array}{c}\text { Gr3 } \\
(n=75)\end{array}$ & $\mathrm{p}^{* *}$ & $\mathrm{p}^{* * *}$ & \\
\hline \multicolumn{8}{|c|}{ Mechanical resistance of erythrocytes, $\%$} \\
\hline Before CPB & $55.62 \pm 15.21$ & $53.16 \pm 16.96$ & 0.970 & $58.62 \pm 19.8$ & 0.940 & 0.520 & \multirow{2}{*}{$\mathrm{p}<0.001$} \\
\hline After CPB & $70.4 \pm 13.92$ & $68.88 \pm 15.56$ & 1.00 & $79.83 \pm 15.68$ & $>0.01$ & $>0.01$ & \\
\hline \multicolumn{8}{|c|}{ Time of acid hemolysis $50 \%$ of erythrocytes, sec. } \\
\hline Before CPB & $235.6 \pm 39.18$ & $232.6 \pm 41.96$ & 1.00 & $228.1 \pm 36.49$ & 0.90 & 0.99 & \multirow{2}{*}{$\mathrm{p}<0.001$} \\
\hline After CPB & $172.9 \pm 33.5$ & $151.3 \pm 31.33$ & 0.02 & $132.9 \pm 33.04$ & $>0.01$ & 0.05 & \\
\hline \multicolumn{8}{|c|}{ Osmotic resistance of erythrocytes, sec. } \\
\hline Before CPB & $491.6 \pm 245.3$ & $501.1 \pm 240.6$ & 1.00 & $456.9 \pm 239.7$ & 0.96 & 0.88 & \multirow{2}{*}{$\mathrm{p}<0.001$} \\
\hline After CPB & $368.9 \pm 200.3$ & $362.4 \pm 179.9$ & 1.00 & $247.3 \pm 129.4$ & 0.03 & 0.05 & \\
\hline
\end{tabular}

Note: ${ }^{*} \mathrm{p}-$ the difference in parameters between $\mathrm{Cr} 1$ and Gr2 is statistically significant $(\mathrm{p}<0.05)$; ** - the difference in parameters between $\mathrm{Cr} 1$ and $\mathrm{Gr} 3$ is statistically significant $(\mathrm{p}<0.05)$; *** - the difference in parameters between $\mathrm{Cr} 2$ and $\mathrm{Gr} 3$ is statistically significant $(\mathrm{p}<0.05)$.

The analysis of erythrocyte membrane permeability (EMP) for urea solution revealed that the level of 50\% erythrocytes hemolysis in urea solution after CPB starting from dilution of hypotonic solutions of urea and sodium chloride in a ratio of 45:55 was higher in Gr 3 compared with $\mathrm{Gr} 1$ and $\mathrm{Gr} 2(\mathrm{p}>0.01)$. The same tendency remained in dilution 55:45, 60:40. The difference in EMP\% between Grland Gr2 is no statistically significant at all dilutions (Fig.3).

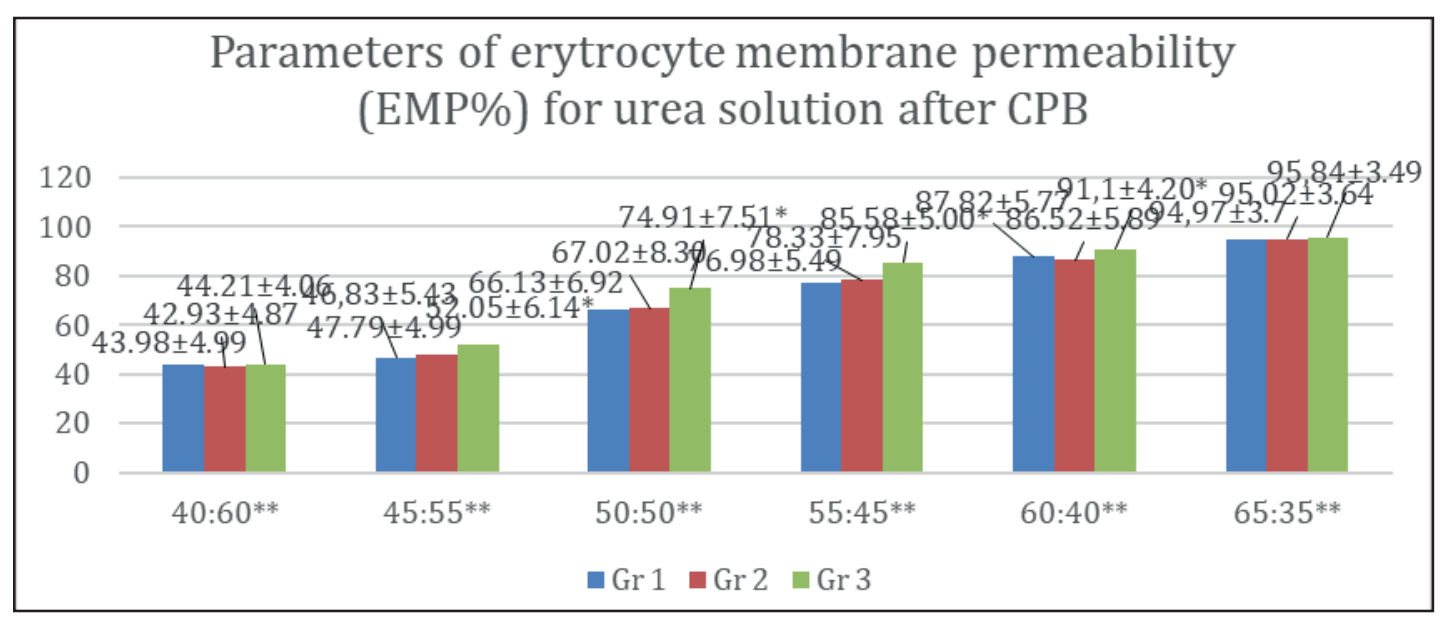

Fig.3. Parameters of erythrocyte membrane permeability (EMP\%) for urea solution after CPB

Note: * the difference in EMP\% is statistically significant $(\mathrm{p}<0.05)$ in Gr 3 compared with Gr1 and Gr2.

** The ratio of hypotonic solutions of urea and sodium chloride. 
Conducted investigations demonstrated that lower levels of hemolysis, greater resistance to mechanical hemolysis, ORE, EMP, and acid hemolysis in Gr2 be caused by FDP protection of cells from physical and chemical damaging factors. Decreased ORE is possible with glucose-6-phosphate dehydrogenase deficiency in erythrocytes and activation of lipid peroxidation $[5,9,10]$.

Level of $\mathrm{HB}$, Ht and RBC at 10 min. CPB-time in three groups was less due to hemodilution. At this stage, MCV was decreased by hyperosmolar prime which had an equally impact on RBC in the three groups. Phosphorus level in Gr2 after perfusion confirms that intravenous administration of PDF before surgery leads to the correction of hypophosphatemia and its prevention after $\mathrm{CPB}$.

We assume the increase in MCV3 at $60 \mathrm{~min}$. CPBtime and after CPB connected with swelling of the cells and their membranes because there were no statistically significant difference in $\mathrm{MCH} 3$ at $60 \mathrm{~min}$. $\mathrm{CPB}$-time and $\mathrm{MCH} 3$ after $\mathrm{CPB}$ compared to $\mathrm{MCH} 3$ before $\mathrm{CPB}(\mathrm{p}=$ 0.447 ), but there was a relative decrease in $\mathrm{MCHC} 3$ at 60 min. CPB-time and MCHC 3 after perfusion compared to $\mathrm{MCH} 3$ before $\mathrm{CPB}(\mathrm{p}<0.01)$. All thus $\mathrm{MCH} 3$ before and after $\mathrm{CPB}$ does not change $(\mathrm{p}=0.661)$, but $\mathrm{MCHC}$ decreases connected with the cell volume increases. $\mathrm{MCHC}$ is a parameter that reflects the $\mathrm{RBC}$ hydration state and is dependent on RBC volume, RBC membrane loss, and water content. We also associate an increase in MCV3 with a higher peripheralization of reticulocytes in Gr3, as a reaction to more hemolysis and tissue hypoxia.

Dynamic of RDWa3, RDW\%3 occurs possibly due to more destruction macro - and microcytes on oxygenator membranes and more release of reticulocytes. It is consistent with higher hemolysis in Gr 3 compared with Gr1 and Gr 2.

Revealed shape and size changes during the morphological study in Gr3 is additional evidence of their defective state after CPB. It can indicate the presence of tissue hypoxia.

\section{CONCLUSIONS}

1. Before CPB $16.8 \%$ of cases of hypophosphatemia and $26.6 \%$ of the clear tendency to ones indicate the initial energy deficiency in cardiac surgery patients.

2. After CPB the level of phosphorus in $\mathrm{Grl}$ and $\mathrm{Gr}$ 3 decreased compared to the before CPB level. In Gr2, where the drug FDP was used, the phosphorus level has been adjusted by administration of FDP during CPB.

3. Data of plfHb, mechanical, osmotic resistance of erythrocytes, and time of acid hemolysis of $50 \%$ of erythrocytes in Gr 3 after CPB indicated more lesion of erythrocytes and the decrease in their resistance compared to Gr1 and Gr 2.

4. The use of FDP and AdC increase the resistance of erythrocytes to the action of traumatic factors.

5. Time of acid hemolysis $50 \%$ of erythrocytes was better in Gr1 using adaptation composition.

6. After CPB in the Gr3 there was a greater release of reticulocytes, echinocytes and spherocytes into the peripheral blood.

\section{LITERATURE}

1. Major M. R., Wong V. W., Nelson E. R. et al. The foreign body response: At the interface of surgery and bioengineering. Plast Reconstr Surg. 2015. 135(5). P. 1489-98. doi: https://doi.org/10.1097/ prs.0000000000001193

2. Pernow J., Mahdi A., Yang J., Zhou Z. Red blood cell dysfunction: a new player in cardiovascular disease. Cardiovascular research. 2019. 115(11). P. 1596-1605.

3. Grygorczyk R., Orlov S. N. The effect of hypoxia on the properties of erythrocyte membranes - importance for intravascular hemolysis and purinergic blood flow control. Front. Physiol. 2017. 8. P. 1110. doi: https:// doi.org/10.3389/fphys.2017.01110.

4. Zhang H., Shen Z., Hogan B., Barakat A. ATP Release by Red Blood Cells under Flow: Model and Simulations. Biophysical journal. 2018. 115(11). P. 2218-29.

5. Строение и функция эритроцита в норме и при критических состояниях / В. В. Мороз. Общая реаниматология. 2012. VIII (1). 52-60.
6. Дерюгина А. В., Бояринов Г. А., Симутис И. С., Бояринова Л. В., Азов Н. А. Морфологические и метаболические показатели эритроцитов при обработке озоном эритроцитарной массы. Общая реаниматология. 2018. 14(1). 40-49.

7. Dogra N., Puri G., Rana S. Glucose-6-phosphate dehydrogenase deficiency and cardiac surgery. Perfusion. 2010. 25(6). P. 417-421.

8. Garazi E., Bridge S., Caffarelli A., Ruoss S. Acute cellular insulin resistance and hyperglycemia associated with hypophosphatemia after cardiac surgery. A\&A Practice. 2015. 4(2). 22-25.

9. Alva N., Alva R., Carbonell T. Fructose 1,6-Biphosphate: A summary of its cytoprotective mechanism. Current Medicinal Chemistry. 2016. 23(39). P. 4396-4417.

10. Мальцева И. В. Характеристика резистентности эритроцитов у кардиохирургических больных с различной степенью выраженности постперфузионного гемолиза. Вестник сибирской медицины. 2013. 
12(1). P. 69-74. (RU) doi: https://doi.org/10.20538/1 682-0363-2013-1-69-74

11.Celkan T. T. What does a hemogram say to us? Turk Pediatri Ars. 2020. 55(2). P. 103-116 doi: https://doi. org/10.14744/turkpediatriars.2019.76301

12.Адаптуюча композиция для обробки внутришной поверхности контура оксугенатора при кардиохирургических операциях: патент Украины № 141109 України 2020. URL: https://base.uipv.org/searchINV/ search.php?action=search

13.Спосіб обробку поверхні контуру оксігенатора при кардіохірургічних операціях: пат України № 140413. 2020. URL: https://base.uipv.org/searchINV/search. php?action $=$ search

14.Cherniy V. I., Sobanska L. O., Lazarenko O. M. et al. Influence of oxygenator extracorporal circuit treatment with adaptation composition (AdC) on morphological changes of erytrocytes. Clinical and Preventive Medicine. 2020. 13(3). 86-97 doi: https://doi.org/10. 31612/2616-4868.3(13).2020.10

15.The method of cardiopulmonary bypass. Patent Ukrainy № 140409. 2020. URL: https://base.uipv. org/searchINV/search.php?action=search

16. Composition of prime solutions of oxygenator. Patent Ukrainy № 140427. 2020. URL: https://base.uipv.org/ searchINV/search.php?action=search
17. Мурыгина О. И., Жукова Е. Р., Петрова О. В., Никулина Д. М. Референтные интервалы содержания свободного гемоглобина при исследовании гемоглобинцианидным методом на биохимическом автоматическом анализаторе ILAB PLUS 300. Наука и инновации в медицине. 2019. 4(3). 4-7.

18.Asatryan T. T., Gaikovaya L. B., Slepisheva V. V. The value of the acidified glycerol lysis test with a graphical determination for screening of hereditary spherocytosis. Translational Medicine. 2019. 6(6). 51-59.

19. Мальцева И. В. Характеристика резистентности эритроцитов у кардиохирургических больных с различной степенью выраженности постперфузионного гемолиза. Бюллетень сибирской медицины. 2013. 12(1). 69-74.

20.Бадалова 3. А. Додхоев Д. С. Показатели сорбционной способности и проницаемости эритроцитарных мембран у детей и новорожденных, проживающих в зоне повышенного радиационного фона. Вестник Авиценный. 2019. 21(4). 597-602.

21.Влияние различных концентраций гомоцистеина на динамику кислотного гемолиза / Чучкова Н. Н. и др. Здоровье, демография, экология финно угорских народов. 2015. 4. 64-65.

\section{REFERENCES}

1. Major, M. R., Wong V. W., Nelson E. R. et al. (2015). The foreign body response: At the interface of surgery and bioengineering. Plast Reconstr Surg., 135(5), 1489-98. doi: https://doi.org/10.1097/ prs.0000000000001193

2. Pernow, J., Mahd, i A., Yang, J., Zhou Z. (2019). Red blood cell dysfunction: a new player in cardiovascular disease. Cardiovascular research, 115(11), 1596-1605.

3. Grygorczyk, R., Orlov, S. N. (2017). The effect of hypoxia on the properties of erythrocyte membranes - importance for intravascular hemolysis and purinergic blood flow control. Front.Physiol., 8, 1110. doi: https:// doi.org/10.3389/fphys.2017.01110.

4. Zhang, H., Shen, Z., Hogan, B., Barakat, A., Misbah, C. (2018). ATP Release by Red Blood Cells under Flow: Model and Simulations. Biophysical journal, 115(11), 2218-29.

5. Moroz, V. V., Golubev, A. M ., Afanasev, A. V., Kuzolev, A. N., Sergunova, V. A., Gudkova V. A., et al. (2012). Stroenie i funktsiia eritrotsita v norme i pri kriticheskich sostoianiiach [The structure and function of the erythrocyte in normal and critical conditions]. General resuscitation, VIII (1), 52-60. [in Russian].

6. Deriugina, A. V., Boiarinov, G. A., Simutis I. S., Boiarinova, L. V., Azov, N. A. (2018). Morfologicheskie I metabolicheskie pokazateli eritrotsitov pri obrabotke ozonom eritrotsitarnoi masy [Morphological and metabolic parameters of erythrocytes during ozone treatment of erythrocyte mass.]. General resuscitation, 14(1), 40-49. [in Russian]

7. Dogra, N., Puri, G, Rana, S. (2010). Glucose-6-phosphate dehydrogenase deficiency and cardiac surgery. Perfusion, 25(6), 417-421.

8. Garazi, E., Bridge, S., Caffarelli, A., Ruoss, S. (2015). Acute cellular insulin resistance and hyperglycemia associated with hypophosphatemia after cardiac surgery. A\&A Practice, 4(2), 22-25.

9. Alva, N., Alva, R., Carbonell, T. (2016). Fructose 1,6-Biphosphate: A summary of its cytoprotective mechanism. Current Medicinal Chemistry, 23(39), 4396-4417.

10. Maltseva, I. V. (2013). Kharakteristika rezistentnosti eritrotsitov u kardiokhirurgicheskich bolnykh s razlichnoi stepeniu vyrazhennosti postperfuzionnogo gemoliza [Characteristic of resistance of erythrocytes in cardiosurgical patients with various degree of manifestation of postperfusion hemolysis]. Bulletin of Siberian Medicine, 12(1), 69-74. (RU) doi: https:// doi.org/10.20538/1682-0363-2013-1-69-74

11.Celkan, T. T. (2020). What does a hemogram say to us? Turk Pediatri Ars, 55(2), 103-116 DOI: https://doi. org/10.14744/turkpediatriars.2019.76301 
12.Adaptuiucha kompozytsiia dlia obrobky vnutrishnoi poverkhni konturu oksugenatora pry kardiokhirurgichnykh operaciiakh [Adaptation composition for treatment of surface of the oxygenator circuit during cardiac surgery]. Sobanska, L. O., Cherniy, V. I., Lazarenk, o O. M. et al. (2020). Patent Ukrainy № 141109. Available from: https://base.uipv. org/searchINV/search.php?action=search

13.Sposib obrobku poverkhni konturu oksygenatora pry kardiokhirurgichnykh operaciiakh [The method of surface treatment of the oxygenator circuit during cardiac surgery]. (2020). Sobanska, L. O., Cherniy, V. I., Lazarenko, O. M. et all. Patent Ukrainy № 140413. Available from: https://base.uipv.org/searchINV/search. php?action $=$ search

14. Cherniy, V. I., Sobanska, L. O., Lazarenko, O. M. et al. (2020). Influence of oxygenator extracorporal circuit treatment with adaptation composition (AdC) on morphological changes of erytrocytes. Clinical and Preventive Medicine, 13(3), 86-97 DOI: https://doi. org/10.31612/2616-4868.3(13).2020.10

15.The method of cardiopulmonary bypass (2020). Sobanska, L. O., Cherniy, V. I. Patent Ukrainy № 140409. URL: https://base.uipv.org/searchINV/ search.php?action $=$ search

16. Composition of prime solutions of oxygenator (2020). Sobanska, L. O., Cherniy, V. I. Patent Ukrainy № 140427. URL: https://base.uipv.org/searchINV/ search.php?action $=$ search

17. Murygina O. I., Zhukova E. R., Petrova, O. V., Nikulina, D. M. (2019). Referentnye intervaly soderzhaniia svobodnogo gemoglobina pri issledovanii gemoglobintsianidnym metodom na biokhimicheskom avtomaticheskom analizatore ILAB 300 PLUS [Reference intervals of the content of free hemoglobin in the study of the hemoglobin cyanide method on an automatic biochemical analyzer ILAB 300 PLUS]. Science and innovation in medicine, 4(3), 4-7. [in Russian].

18.Asatryan, T. T., Gaikovaya, L. B., Slepisheva, V. V. (2019). The value of the acidified glycerol lysis test with a graphical determination for screening of hereditary spherocytosis. Translational Medicine, 6(6), 51-59.

19. Maltseva, I. V. (2013). Kharakteristika rezistentnosti eritrotsitov u kardiokhirurgicheskich bolnykh s razlichnoi stepeniu vyrazhennosti postperfuzionnogo gemoliza [Characteristics of the resistance of erythrocytes in cardiac surgery patients with varying degrees of severity of postperfusion hemolysis]. Bulletin of Siberian Medicine, 12(1), 69-74. [in Russian].

20.Badalova, Z. A., Dodkhoev, D. S. (2019). Pokazateli sorbtsionnoi sposobnosti I pronitsaemosti eritrotsitarnykh membran u detei i novorozhdennykh, prozhivaiushchikh $\mathrm{v}$ zone povyshennogo radiatsionnogo fona [Indicators of the sorption capacity and permeability of erythrocyte membranes in children and newborns living in the zone of increased radiation background]. Avicenny Bulletin, 21(4), 597-602. [in Russian].

21. Chuchkova, N. N., Kormilina, N. V., Kavunienko, A. A., Vasiliev, M. A., Volkova, A. G. (2015). Vliianiie razlichnykh kontsientracii gomotsistieina na dinamiku kislotnogo giemoliza [Influence of various concentrations of homocysteine on the dynamics of acid hemolysis]. Health, demography, ecology of the Finno-Ugric peoples, 4, 64-65. [in Russian]. 


\section{Резюме}

\section{ЗАХИСТ ЕРИТРОЦИТІВ ПРИ ШТУЧНОМУ КРОВООБІГУ}

\section{В. І. Черній, Л. О. Собанська, Н.В. Шестак}

Державна наукова установа «Науково-практичний центр профілактичної та клінічної медицини» Державного управління справами

Мета дослідження. Метою даної роботи було поліпшення біосумісності екстракорпорального контуру за рахунок використання «адаптуючої композиції (АК), зменшення негативного впливу перфузії на стан еритроцитів завдяки введенню фруктозо-1,6-дифосфата (ФАФ) для зменшення інтраопераційного гемолізу і тканинної гіпоксії.

Матеріал і методи. У дослідження було включено 225 осіб, яким були виконані кардіохірургічні операції з використанням штучного кровообігу (ШК). Ао першої групи увійшли пацієнти, у яких контур оксигенатора був оброблений «адаптуючою композицією», до другої групи включені пацієнти, яким вводили ФАФ, третя група була контрольною. Обробку оксигенатора АК і введення ФАФ проводили згідно з протоколом. Забір крові і мазки брали на 4 етапах: до ШК, на 10 хв. ШК, на 60 хв. ШК (етап зігрівання) і після відключення ШК. Аослілжували параметри: гемоліз, осмотичну, механічну, резистентність еритроцитів, проникність еритроцитарної мембрани, кислотний гемоліз, мазки крові фарбували по Паппенгейму.

Результати. Були отримані кращі показники еритроцитарних індексів, гемолізу, осмотичної, механічної, кислотної, сечовинної резистентності еритроцитів в групах, де використовували фруктозо-1,6-дифосфат і «адаптуючу композицію». У доопераційному періоді гіпофосфатемія була у 16,8\% 3225 пацієнтів, а у 26,6\% з 225 пацієнтів спостерігалася нижня межа норми вмісту фосфору в крові. Після операції в групі, де вводили фруктозо-1,6-дифосфат, гіпофосфатемії не було. Білыш високий викид ретикулоцитів, ехіноцитів і сфероцитів в кров після перфузії спостерігався в контрольній групі.

Висновки. Використання АК і ФАФ під час штучного кровообігу сприяє зниженню гемолізу і кращому стану еритроцитів.

Ключові слова: штучний кровообіг, фруктозо-1,6-дифосфат, адаптуюча композиція, еритроцити, гемоліз, середній об'єм еритроцитів, розподіл еритроцитів по ширині, середня концентрація гемоглобіну в еритроциті, гіпофосфатемія. 


\section{Резюме}

\section{ЗАЩИТА ЭРИТРОЦИТОВ ПРИ ИСКУССТВЕННОМ КРОВООБРАЩЕНИИ}

\section{В. И. Черний, Л. А. Собанская, Н. В. Шестак}

ГНУ «Научно-практический центр профилактической и клинической медицини» ГУД

Цель исследования. Целью данной работы было улучшение биосовместимости экстракорпорального контура за счет использования «адаптирующей композиции» (АК), уменьшение негативного влияния перфузии на состояние эритроцитов благодаря введению фруктозо-1,6-дифосфата (ФАФ) для уменьшения интраоперационного гемолиза и тканевой гипоксии.

Материалы и методы. В исследование включены 225 человек, которым была выполнена кардиохирургическая операция с использованием искусственного кровообращения (ИК). В первую группу вошли пациенты, у которых контур оксигенатора был обработан «адаптирующей композицией», во вторую группу включены пациенты, которым вводили ФАФ, третья группа была контрольной. Обработку оксигенатора АК и введение ФАФ проводили согласно протоколу. Забор крови и мазки брали на 4 этапах: перед ИК, на 10 мин. ИК, на 60 мин. ИК (этап согревания) и после отключения ИК. Исследовали параметры: гемолиз, осмотическую, механическую, резистентность эритроцитов, проницаемость эритроцитарной мембраны, кислотный гемолиз, мазки крови окрашивали по Паппенгейму.

Результаты. Были получены лучшие показатели эритроцитарных индексов, гемолиза, осмотической, механической, кислотной, мочевинной резистентности эритроцитов в группах, где использовали фруктозо-1,6-дифосфат и «адаптирующую композицию». В предоперационном периоде гипофосфатемия была у $16,8 \%$ из 225 пациентов, а у 26,6\% из 225 пациентов наблюдалась нижняя граница нормы содержания фосфора в крови. После операции в группе, где вводили фруктозо-1,6-дифосфат, гипофосфатемии не было. Более высокий выброс ретикулоцитов, эхиноцитов и сфероцитов в кровь после перфузии наблюдался в контрольной группе.

Выводы. Использование АК и ФАФ при искусственном кровообращении способствует снижению гемолиза и лучшему состоянию эритроцитов.

Ключевъе слова: искусственное кровообращение, фруктозо-1,6-дифосфат, адаптирующая композиция, эритроциты, гемолиз, средний объем эритроцитов, распределение эритроцитов по ширине, средня концентрация гемоглобина в эритроците, гипофосфатемия.

Інформація про авторів знаходиться на сайті http://www.cp-medical.com.

Дата надходження до редакції - 14 лютого 2021 року 